\title{
Effect of Acetaminophen on Viability of HeLa Cells
}

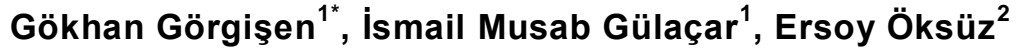 \\ ${ }^{1}$ Department of Medical Biology, Faculty of Medicine, V an Yuzuncu Yil University, Van, Turkey \\ ${ }^{2}$ Division of Pharmacology, Malatya Training and Research Hospital, Malatya, Turkey
}

\begin{abstract}
Acetaminophen is a widely used analgesic to release pain and reduce fever. Overdose medication could lead to serious medical conditions such as hepatotoxicity and liver failure. In addition to its cytotoxicity effects, it has an anti-proliferative effect in human cancer cells. In this study it is aimed to determine the apoptotic effect of acetaminophen in HeLa cells. In this perspective, HeLa cells were treated with different concentrations of acetaminophen at three different exposure times. Cell viability was determined by MTT analysis. Results showed that acetaminophen inhibited viability of HeLa cells. Its cytotoxic effect depends on exposure time and concentration. Prolonged exposure of acetaminophen led to decrease in cell survival even at minimum concentrations.
\end{abstract}

Key Words: Acetaminophen, Paracetamol, Cervical cancer, HeLa cells, Apoptosis

\section{Introduction}

Acetaminophen, also known as paracetamol, is commonly used analgesic and antipyretic with minimal side effects that are rare when used at therapeutic dosage. On the other hand, overdose of acetaminophen is toxic and may lead to kidney failure and fatal hepatoxicity $(1,2)$. Acetaminophen is one of the Nonsteroidal anti-inflammatory drugs (NSAID) such as aspirin. These drugs decreased cancer risk via multiple cellular pathways $(3,4)$. In this perspective, many studies showed acetaminophen inhibits the cell proliferation and induce apoptosis in tumor cultured cell lines through conversion of acetaminophen by cytochrome p450 to reactive metabolite N-acetyl-p-benzoquinoneimine (NAPQI) (5-8). Boulares et al. also showed that, acetaminophen induced DNA fragmentation directly, release of cytochrome $\mathrm{c}$ and activation of caspases. All these traits are important key factors that can cause programmed cell death (1-9).

Cervical cancer is one of the most common gynecological cancer which involves abnormal cell proliferation and cell migration of the female uterine cervix (10). According to the World Cancer Research Fund International cervical cancer contributed almost $8 \%$ of all newly diagnosed cancers in 2012 (11). Human papillomavirus (HPV) infections are the main reason of the cervical cancers. Chemotherapy can be used for the treatment of cervical cancers women with early cervical cancer, especially those patients with advanced stages. However, most patients develop ototoxicity or resistance to therapy $(10,12)$. Therefore, new therapeutic approaches and anti- carcinogenic novel compounds should be developed in cancer treatments.

In this study, it was aimed to explore the cytotoxic effect of acetaminophen on HeLa cells in time dependent manner.

\section{Materials and Methods}

Cell Culture and Reagents: HeLa cells were grown in a saturated humidity atmosphere containing $95 \%$ and $5 \%$ CO2 at $37 \mathrm{oC}$ in Dulbecco's Modified Eagle Medium (DMEM) (Biowest) supplemented with 10\% heat inactivated Fetal Bovine Serum (FBS) (Biowest), $2 \mathrm{mM} \mathrm{L-}$ Glutamine (PanTech), $100 \mathrm{mg} / \mathrm{ml}$ penicillin, 50 $\mathrm{ug} / \mathrm{ml}$ streptomycin, and $1 \mathrm{mM} \mathrm{L}$-glutamine.

Treatments and MTT Analysis: Cell viability was tested by MTT analysis. The cells were plated at a density of 5 thousand cells per well in a 96-well microtiter plates with 6 replicates. Cells were treated at different concentrations $(0,0.1,0.2,0.5$, $1,3,5,7,9 \mathrm{mg} / \mathrm{ml}$ ) of acetaminophen (paracetamol) and Phosphate Buffer Saline (PBS) as a vehicle for 24, 48 and 72 hours. At the end of the incubation times, $20 \mu \mathrm{L}$ of MTT $(5 \mathrm{mg} / \mathrm{mL})$ solution was 
Table 1. Calculated IC50 values of acetaminophen in HeLa cells in time dependent manner

\begin{tabular}{cc}
\hline Exposure Time & Calculated IC50 Values \\
\hline $24 \mathrm{~h}$ & $2,568 \mathrm{mg} / \mathrm{ml}$ \\
$48 \mathrm{~h}$ & $1,8 \mathrm{mg} / \mathrm{ml}$ \\
$72 \mathrm{~h}$ & $0,658 \mathrm{mg} / \mathrm{ml}$ \\
\hline
\end{tabular}

added for 4 hours at $37^{\circ} \mathrm{C}$ in an incubator, then medium was removed and DMSO $(100 \mu \mathrm{L})$ was added to dissolve the formazan crystals. The plates were shielded from light using a foil and left in an orbital shaker maintained at 600 revolutions/minute for 5 minutes. The amount of MTT formazan product formed was determined by measuring absorbance at $540 \mathrm{~nm}$, with $690 \mathrm{~nm}$ as the reference wavelength.

Statistical Analysis: All data were presented as the mean \pm SEM from three independent experiments for MTT analyses. Each MTT analyses were performed with six replicates. Two-way analysis (ANOVA) was used for multiple comparison in data analyses. The statistical analyses were performed using Prism 7 (GraphPad Software, USA)

\section{Results}

Effect of acetaminophen on HeLa cells growth: When HeLa cells were treated with different concentrations of acetominophen for different lengths of time, MTT results showed that acetaminophen led to decrease in survival of the cells in a concentration dependent manner. To determine IC50 value, the optimum dosage which causes $50 \%$ inhibition of cancer cell growth, GraphPad Prism analysis was performed and results are shown in Table 1 . After $24 \mathrm{~h}$ incubation time, IC50 value of acetaminophen was $2,586 \mathrm{mg} / \mathrm{ml}$ and it showed its cytotoxic activity at $1,8 \mathrm{mg} / \mathrm{ml}$ after $48 \mathrm{~h}$ and at $0,658 \mathrm{mg} / \mathrm{ml}$ after 72 $h$ treatments. IC50 values of acetaminophen significantly decreased in time dependent manner.

Lower acetaminophen concentrations have no impact on cell viability at 24 and $48 \mathrm{~h}$ treatments (Figure 1a, Figure 1b). 20\% of cell growth inhibition was detected after $24 \mathrm{~h}$ and $48 \mathrm{~h}$ treatment with $1 \mathrm{mg} / \mathrm{ml}$ concentration of acetaminophen. Even this concentration of acetaminophen inhibited cell growth at any point of time, its inhibition effect increased with prolonged exposure time. It was observed that 72 h. exposure with acetaminophen led to $70 \%$ decrease in viability of the cells at the same concentration (Figure 1c). Growth inhibition with lower concentrations of acetaminophen was determined as $17 \%$ at $0,2 \mathrm{mg} / \mathrm{ml}, 36 \%$ at 0,5 $\mathrm{mg} / \mathrm{ml}$ and $69 \%$ at $1 \mathrm{mg} / \mathrm{ml}$ after $72 \mathrm{~h}$ (Figure 1c).

\section{Discussion}

Acetaminophen is a widely used drug to relieve pain and reduced fever however its higher doses could led to acute liver failure and critical health problems (13). Many studies also reported that it induces the apoptosis and inhibits cell proliferation. Its apoptotic effects of acetaminophen have been demonstrated in cell culture such as primary hepatocytes, lymphocytes and neuroblastoma cells $(8,9,14,15)$. In this study it was shown that acetaminophen also has an antiproliferative effect on HeLa cells. Ruppova et al. has demonstrated that acetaminophen induced apoptosis through DNA damage in HeLa cells but their acetaminophen concentrations and their incubation time were so limited (16). Therefore, evaluation of effects of prolonged and higher doses acetaminophen was not possible. It was confirmed that effects of acetaminophen on cell survival depends on its concentration and exposure time. Prolonged exposure time of acetaminophen inhibited cell survival, even at lower doses in in vitro conditions. Decrease in IC50 values of acetaminophen during elevated incubation times has also confirmed that hypothesis.

Underlying the molecular mechanism in apoptotic process of acetaminophen remains unclear but many studies showed that NSAIDs inhibits the cell growth via cyclooxygenase (COX) dependent and independent pathways (17-19). In in vitro, COX 2 inhibitors inhibit the endometrium cancer cell proliferations significantly $(20,21)$. Metaanalyses results showed that, COX2 expressions significantly increased in cervical cancer patients and they suggested that cyclooxygenase inhibitors might be useful for the treatment of cervical cancers (22). In this study, the molecular pathways that induce cell death were not explored but it is hypothesized that acetaminophen may show its antineoplastic activity through the inhibition of COX2 activity in HeLa cells.

Acetaminophen also induces apoptosis via JNK pathways (23). JNKs are the member of stress

East J Med Volume:24, Number:1, January-March/2019 

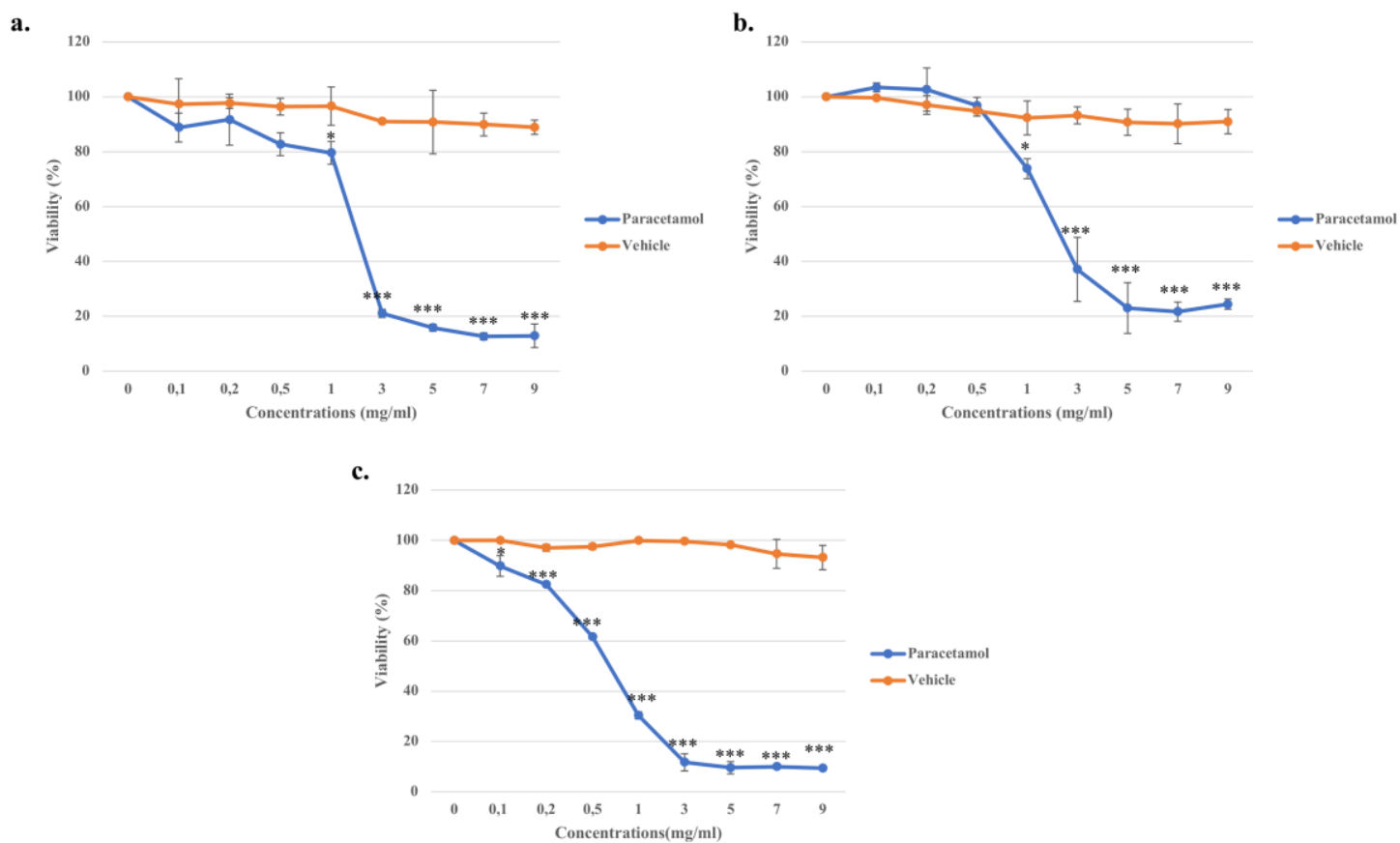

Fig. 1. Effects of different concentrations of acetaminophen against HeLa cell viability $\left({ }^{*} \mathrm{p}<0.05,{ }^{*} * *_{\mathrm{p}}<0.0001\right)$ a) $\%$ cell viability of HeLa cells after $24 \mathrm{~h}$ treatment with acetaminophen b) \% cell viability of HeLa cells after $48 \mathrm{~h}$ treatment with acetaminophen c) \% cell viability of HeLa cells after $72 \mathrm{~h}$ treatment with acetaminophen

activated Serine/Thronine kinases (24). Acetaminophen induced liver toxicity has a strong relationship with JNK activation and increased JNK activation is correlated with ovarian cancer cell death in in vitro $(2,25)$. According to these previous studies, acetaminophen may lead to induce apoptosis by JNK activation in HeLa cells too.

In summary, this study showed that acetaminophen induced cell death depends on its exposure time and concentration through different cellular signaling pathways in in vitro and prolonged exposure of lower dose acetaminophen inhibited HeLa cell survival.

\section{References}

1. Boulares AH, Ren T. Mechanism of acetaminophen-induced apoptosis in cultured cells: roles of caspase-3, DNA fragmentation factor, and the $\mathrm{Ca} 2+$ and $\mathrm{Mg} 2+$ endonuclease DNAS1L3. Basic Clin Pharmacol Toxicol 2004; 94: 19-29.

2. Bush SH, Tollin S, Marchion DC, et al. Sensitivity of ovarian cancer cells to acetaminophen reveals biological pathways that affect patient survival. Mol Clin Oncol 2016; 4: 399-404.

3. Shiff SJ, Rigas B. The role of cyclooxygenase inhibition in the antineoplastic effects of nonsteroidal antiinflammatory drugs (NSAIDs). J Exp Med 1999; 190: 445-450.

4. Thun MJ, Henley SJ, Patrono C. Nonsteroidal anti-inflammatory drugs as anticancer agents: mechanistic, pharmacologic, and clinical issues. J Natl Cancer Inst 2002; 94: 252-266.

5. Chang W, Barve S, Chen TS. p-Aminophenolinduced cytotoxicity in Jurkat $T$ cells: protective effect of 2(RS)-npropylthiazolidine-4(R)-carboxylic acid. J Biochem Mol Toxicol 2012; 26: 71-78.

6. Dahlin DC, Miwa GT, Lu AY, Nelson SD. Nacetyl-p-benzoquinone imine: a cytochrome P450-mediated oxidation product of acetaminophen. Proc Natl Acad Sci U S A 1984; 81: 1327-1331.

7. Liang Q, Sheng Y, Ji L, Min Y, Xia Y, Wang Z. Acetaminophen-induced cytotoxicity on human normal liver L-02 cells and the protection of antioxidants. Toxicol Mech Methods 2010; 20: 273-278.

8. Posadas I, Santos P, Cena V. Acetaminophen induces human neuroblastoma cell death through NFKB activation. PLoS One 2012; 7 : e50160.

9. Boulares AH, Zoltoski AJ, Stoica BA, Cuvillier $\mathrm{O}$, Smulson ME. Acetaminophen induces a caspase-dependent and Bcl-XL sensitive apoptosis in human hepatoma cells and lymphocytes. Pharmacol Toxicol 2002; 90: 3850. 
10. Dasari S, Wudayagiri R, Valluru L. Cervical cancer: Biomarkers for diagnosis and treatment. Clin Chim Acta 2015; 445: 7-11.

11. Ferlay J, Soerjomataram I, Dikshit R, et al. Cancer incidence and mortality worldwide: sources, methods and major patterns in GLOBOCAN 2012. Int J Cancer 2015; 136: E359-386.

12. Gao J, Yu H, Guo W, et al. The anticancer effects of ferulic acid is associated with induction of cell cycle arrest and autophagy in cervical cancer cells. Cancer Cell Int 2018; 18 : 102.

13. Wang C, Xu W, Zhang Y, Huang D, Huang K. Poly(ADP-ribosyl)ated PXR is a critical regulator of acetaminophen-induced hepatotoxicity. Cell Death Dis 2018; 9: 819.

14. Ishida Y, Kondo T, Ohshima T, Fujiwara H, Iwakura Y, Mukaida N. A pivotal involvement of IFN-gamma in the pathogenesis of acetaminophen-induced acute liver injury. FASEB J 2002; 16: 1227-36.

15. Shen W, Kamendulis LM, Ray SD, Corcoran GB. Acetaminophen-induced cytotoxicity in cultured mouse hepatocytes: effects of $\mathrm{Ca}(2+)$-endonuclease, DNA repair, and glutathione depletion inhibitors on DNA fragmentation and cell death. Toxicol Appl Pharmacol 1992; 112: 32-40.

16. Ruppova K, Wsolova L, Sedlak J, Horvathova M, Urbancikova M. Detection of apoptotic changes in HeLa cells after treatment with paracetamol and sodium fluoride. Gen Physiol Biophys 1999; 18: 140-146.

17. Simmons DL, Botting RM, Hla T. Cyclooxygenase isozymes: the biology of prostaglandin synthesis and inhibition. Pharmacol Rev 2004; 56: 387-437.
18. Thun MJ, Jacobs EJ, Patrono C. The role of aspirin in cancer prevention. Nat Rev Clin Oncol 2012; 9: 259-267.

19. Ulrich CM, Bigler J, Potter JD. Non-steroidal anti-inflammatory drugs for cancer prevention: promise, perils and pharmacogenetics. Nat Rev Cancer 2006; 6: 130-140.

20. Gao J, Niwa K, Sun W, et al. Non-steroidal anti-inflammatory drugs inhibit cellular proliferation and upregulate cyclooxygenase-2 protein expression in endometrial cancer cells. Cancer Sci 2004; 95(11): 901-7.

21. Ozalp SS, Eren CY, Bostancioglu RB, Koparal AT. Induction of apoptosis and inhibition of cell proliferation by the cyclooxgenase enzyme blocker nimesulide in the Ishikawa endometrial cancer cell line. Eur J Obstet Gynecol Reprod Biol 2012; 164: 79-84.

22. Young JL, Jazaeri AA, Darus CJ, Modesitt SC. Cyclooxygenase-2 in cervical neoplasia: a review. Gynecol Oncol 2008; 109: 140-145.

23. Win S, Than TA, Han D, Petrovic LM, Kaplowitz N. c-Jun N-terminal kinase (JNK)dependent acute liver injury from acetaminophen or tumor necrosis factor (TNF) requires mitochondrial Sab protein expression in mice. J Biol Chem 2011; 286: 35071-35078.

24. Johnson GL, Nakamura K. The c-jun kinase/stress-activated pathway: regulation, function and role in human disease. Biochim Biophys Acta 2007; 1773: 1341-1348.

25. Gunawan BK, Liu ZX, Han D, Hanawa N, Gaarde WA, Kaplowitz N. c-Jun N-terminal kinase plays a major role in murine acetaminophen hepatotoxicity. Gastroenterology 2006; 131: 165-178. 